\title{
Desde a Amazônia acreana: narrativas de TRABALHADORES DESLOCADOS DE ITAIPU - LEITURAS DO "TEMPO PRESENTE" 1
}

\section{Maria Cristina Lobregat ${ }^{2}$}

RESUMO: Este artigo trata da trajetória que envolve homens e mulheres deslocados para a Amazônia acreana após a expropriação de terras em municípios atingidos pelo Lago de Itaipu, em fins da década de 1970. O contexto é o da construção da Usina Hidrelétrica de Itaipu chegando até o momento final com a alagação de propriedades rurais, as desapropriações e deslocamentos das famílias que ali residiam. A abordagem gira em torno do propósito de pensar as práticas culturais e o deslocamento dos trabalhadores no tempo e espaço, a partir de suas narrativas orais. Além dos depoimentos, foram utilizados jornais da época de idealização da construção da usina, com reportagens que procuravam "registrar" o momento conflituoso com os agricultores que seriam expropriados, bem como as propagandas oficiais sobre a "colonização dirigida" para a região amazônica.

PALAVRAS-CHAVE: Itaipu. Amazônia acreana. Narrativas Orais. Modernização. Trabalhadores Rurais.

Em "A invenção do cotidiano: artes de fazer", Michel de Certeau teoriza sobre a escrita como prática moderna e inicia colocando três elementos básicos para que ela aconteça: a página em branco, o texto e a produção de sentido como um ato de transformação. Neste estudo, ao utilizar a metáfora da fabricação de sentidos ao produzir um texto com a finalidade de transformar ou conservar opiniões, percebemos que a escrita que encontramos nos jornais representam aqueles instrumentos discutidos por Certeau e são, portanto, repleto de intenções e representações. O que procuramos é situar em um tempo as causas e consequências da construção da Usina de Itaipu através de fontes historiográficas e de jornais, e, simultaneamente, colocaremos na mesma discussão as narrativas orais de deslocados. Seguindo as pistas deixadas pelos jornais,

\footnotetext{
${ }^{1}$ Originalmente apresentado como parte do segundo capítulo da Dissertação de Mestrado "Pedra que canta', lembranças que latejam: vozes de deslocados de Itaipu para a Amazônia Acreana", defendida do ano de 2013, junto ao Programa de Pós-Graduação em Letras: Linguagem e Identidade da UFAC, nível de mestrado.

${ }^{2}$ Mestre em Letras: Linguagem e Identidade, Professora do Instituto Federal do Acre
} 
publicações e narrativas orais, compreendemos as representações feitas sobre a realidade e o desconforto causado pelo deslocamento, ou, como ele pode levar à necessidade e à capacidade de produzir um novo espaço a partir de estratégias individuais e/ou coletivas.

Nessa direção, sentimos a necessidade de analisar os depoimentos daqueles "migrantes" ou "deslocados" que chegaram ao Acre há três décadas, numa viagem que ultrapassa o tamanho gigantesco do Lago de Itaipu. Nesse caso, para ir além é preciso voltar ao começo, ou seja, a um ponto inicial, como forma não de buscar explicações de causa e efeito, mas de compreender os momentos de ruptura com determinados modos de vida ou práticas culturais desses sujeitos e seu consequente deslocamento para as "terras prometidas" dos "confins da Amazônia", para lançarmos mão de uma terminologia cunhada por Craveiro Costa (1998).

Encaramos a situação das famílias entrevistadas além de uma "clássica" migração, e incorporamos a ideia de mudança forçada e a impossibilidade de retorno. O deslocamento, quando pensado como uma forma de assentamento dirigido e pós-alagamento de Itaipu, quando não há o desejo de sair do local de origem, vai além do conceito de migração, pois esta palavra não é capaz de dar sentido completo à experiência de ser expulso do espaço construído. A migração nesse contexto passa a ser uma variante do deslocamento e representa uma das formas de violência contra o homem inserido na sociedade marcada pela modernização.

As pessoas "deslocadas" não queriam, por vontade própria, abandonar as terras onde viviam, mas uma situação além de suas vontades as obrigou a sair o que criou um processo díspar daquilo que convenciona a migração clássica. O migrante, embora também movido por forças exteriores, é ele quem decide mudar, ele deixa sua terra de origem por motivos próprios, enquanto o trabalhador rural tratado nesta pesquisa foi obrigado a deixar sua terra por forças externas a sua vontade. Pessoas atingidas por barragens não possuem a opção de ficar, há um controle muito mais forte que as move, que as desloca forçadamente, um possível "exílio" que separa o homem de sua terra natal. Após o alagamento do espaço construído e praticado pelas famílias, o retorno torna-se 
uma impossibilidade e assim os sujeitos passarão a reconstruir a possibilidade de pertencimento em outro espaço encontrado.

Edward Said discute o exílio colocando-o de forma que ultrapassa a noção comum de afastamento. Em seu ensaio "Reflexões sobre o exílio", o tema é abordado abrindo diversos aspectos capazes de quebrar conceitos sobre o exílio e alterar a visão que podemos ter da relação entre o homem e o espaço na era da modernidade. A discussão de Said sobre o tema exílio apresenta vários eixos que são representados pelos termos como deslocamentos, imigração, diáspora e refúgio, pois eles ligam-se à quebra de pertencimento e o sentido de exílio revela-se como "uma fratura incurável entre um ser humano e um lugar natal, entre o eu e seu verdadeiro lar" (SAID, 2003, p. 46), e tal ruptura pode acontecer de maneira involuntária como é o caso dos deslocados vindos do Paraná, impedidos de voltar ao lugar de origem, pois este não mais existe após o alagamento. Said ressalta ainda que "embora seja verdade que toda pessoa impedida de voltar para casa é um exilado, é possível fazer algumas distinções entre exilados, refugiados, expatriados e emigrados" (SAID, 2003, p. 54). Nessa direção, incluímos os "deslocados" pelo impedimento que a situação de alagamento da represa os empurrou para outro espaço.

O deslocado envolvido neste estudo é o homem "fora do lugar” (SAID, 2004), é aquele que está ou esteve em movimento, em busca do aconchego de um lar. Esse sujeito possui na sua trajetória de vida a sensação de perda e ruptura refletidas pelo afastamento do espaço de origem onde já havia construído sua vida e cultura, a viagem sem volta foi determinante no contexto dos deslocados. Ao perder o espaço praticado, um novo sentimento se estabeleceu gerando a busca pelo lar e pela casa algo que, simbolicamente, o afastaria da sensação de abandono e rompimento.

O deslocamento de que trata esta pesquisa vai além do movimento nos espaços geográficos, pois não representa unicamente o estado físico, de espaço ou de tempo (GONZÁLEZ, 2010). Ele assume também algo que o identifique como um estado de sentimento de distanciamento enlaçado com perdas, com sentimento de ausência, o sentimento do "não lugar" presente pelas diferenças encontradas. Nesse sentido reforçamos o uso do termo "des- 
locado", caracterizador dos trabalhadores rurais do Sul, homens que tais quais os "exilados" de Said também não possuem formas reais de retorno, portanto, encontram-se em eterno estranhamento por sentirem-se "fora do lugar". Nesse sentido, ao tratarmos da construção de Itaipu e a consequente desapropriação dos espaços praticados no Sul pelas famílias paranaenses, caímos nas discussões envolvendo a violência da modernidade nas formas de tratar o homem gerando situações de deslocamento, migração, expatriação e exílio.

O termo "deslocado" sugere e marca a visão de homem nos processos gerados pelas imposições sociais sofridas na sociedade preocupada com a modernização, pois para significarmos esse homem dentro de uma perspectiva dos estudos culturais, torna-se difícil não ver todas as situações geradas como "deslocamentos". Assim, acreditamos nas relações culturais, nas trocas e na situação multicultural, exatamente, por vermos um homem que está em constante deslocamento, em constante busca pelo seu lugar. Diante disso, colocamos os trabalhadores vindos do Paraná na mesma situação de violência. São homens e mulheres que devido ao anseio de modernização do país foram levados a situações de deslocamento e de posterior construção de novos significados durante as trocas e permanências culturais no espaço que tiveram de construir nos projetos de assentamentos na Amazônia acreana.

Para conhecer os deslocados seguimos no "encalço" das famílias vindas do Paraná na década de 1980. Percorremos os acervos documentais, perscrutando manchetes e notícias de jornais na expectativa de mapear as localidades para onde os atingidos pelas barragens da hidrelétrica, localizada no oeste do Estado do Paraná, foram "enviados". O contexto e os condicionantes histórico-temporais desses deslocamentos também foram colocados no foco desse levantamento nas fontes de pesquisa. Nessa mesma direção, passamos a realizar contatos com diferentes pessoas que poderiam nos fazer chegar aos trabalhadores rurais que foram deslocados para a Amazônia acreana, tendo como preocupação inicial mapear os locais e os contextos históricos de seus deslocamentos para esta região.

Encontramos famílias que vieram de diferentes municípios alagados pela hidrelétrica. Algumas delas viviam em Santa Helena e São Miguel do Iguaçu, outras moravam em uma área de litígio entre Brasil e Paraguai, 
como também no Arquipélago de Ilha Grande, próximo aos Saltos de Guairá. Com isso, conseguimos apreender diferentes situações de deslocamentos, cada família passou por um tipo de abordagem pelas colonizadoras cadastradas ao INCRA, vivenciando formas diferentes de enfrentamento das situações ao deixarem as terras onde viviam. As reações de cada pessoa em relação à situação nova que se apresentava são significativas para identificar as diversas possibilidades experimentadas e que estão na memória como algo vivo e importante para a reordenação do modo de ver e sentir o vivido. O deslocado ao se separar das raízes da terra de origem cria uma relação entre ele o "outro", sempre trafegando pelo ameaçador território do "não-pertencer", algo que o faz querer ser alguém pertencente a algum lugar.

Os entrevistados trabalhavam no cultivo da terra produzindo arroz, feijão, mandioca entre outros, além da criação de pequenos animais para o consumo familiar. A relação dessas pessoas com o campo se caracterizava por uma vivência intensa com o trabalho. A área que ocupavam representava a fonte de sustento, além de garantir no cotidiano o convívio social com grupos semelhantes. Perder a terra em que viviam e trabalhavam significava uma ruptura com tudo aquilo que os identificava enquanto sujeitos sociais.

Nesse envolvimento do homem com a terra entende-se que "o fazer" está ligado com “o ser” e com "o ter". Nas específicas condições em que vive, a força do trabalho liga esse sujeito a outros desejos que se personificam, tomam corpo dentro de relações que são marcadas pelas experiências e pelas relações sociais com os grupos. Para que esse sujeito seja reconhecido, ele necessita do seu trabalho, nesse momento "o fazer" o leva para "o ser". Sendo assim, compreendemos que a experiência do deslocamento vivido pelas famílias entrevistadas faz parte do entendimento que elas têm de vender a força de trabalho e sobreviver, e, as remetem à sujeição da "condição humana" (ARENDT, 2010), uma necessidade em que o viver se impõe, é o pertencer ao mundo. Nesse mesmo caminho julgamos o trabalho como algo da essência humana por ser uma atividade antiga e glorificada na era moderna possibilitando a formação de uma sociedade de trabalhadores, algo que nos remete aos deslocados que também passam por essa situação. Se os trabalhadores sem trabalho é algo ruim, 
trabalhadores rurais sem terra também o é, o que justifica a decisão de homens e mulheres submeterem-se ao deslocamento imposto por saberem que as terras onde viviam e trabalhavam seriam alagadas pela usina.

Transitando entre fontes documentais escritas e orais, bem como percorrendo as linhas traçados por autores que analisam a questão agrária no Brasil, percebemos o quanto o INCRA transformou um "problema" de terras em um "negócio" de terras ao favorecer empresas de colonização que influenciavam famílias de posseiros submeterem-se ao deslocamento para a Amazônia acreana. As famílias aceitavam a promessa de terras produtivas no Norte do país e contribuíam para ocultar a problemática questão agrária no Brasil durante a ditadura militar.

O jornal Gazeta do Acre, em novembro de 1981, estamparia a notícia que o Projeto de Assentamento Dirigido Pedro Peixoto, era um dos locais onde famílias deslocadas estavam sendo assentadas, numa ação desenvolvida pelo INCRA local, reforçando a política de expansão agrícola na região.

Sob a presidência do vice-governador do Estado, José Fernandes do Rego, a Comissão Consultiva de Política Agrícola estará se reunindo [...] para analisar os resultados obtidos pelos projetos de colonização [...]. Estes projetos estão sendo desenvolvidos pela Delegacia Regional do INCRA. Segundo o Decreto assinado pelo Governador Joaquim Macedo, cabe agora à Comissão Consultiva de Política Agrícola sugerir medidas para agilizar a execução desses projetos pelo Plano de Ação do Governo (GAZETA DO ACRE, 19/11/1981).

Acompanhando a pena e a empolgação presentes na reportagem da Gazeta do Acre, é possível antevermos que a lógica dos assentamentos de trabalhadores em áreas às mais adversas, era uma artimanha do governo federal, seguida à risca pelo governo do Acre, que tinha pressa em "agilizar" sua execução. Poucos anos mais tarde, essa "agilidade" e o espírito de aquiescência no deslocamento de famílias provenientes do sul e de outras partes do país para “ocupar” a região, ganhariam novos destaques na imprensa local, evidenciando as consequências não previstas no "Plano de Ação" da gestão Joaquim Macedo/ José Fernandes do Rego. 
O texto aponta características específicas de notícia, privilegia a descrição de ações que seriam concretizadas pela Comissão Consultiva, explicitamente é assumido o tom de propaganda das ações do governo da época ressaltando o propósito desenvolvimentista e de expansão agrícola na região amazônica.

As pessoas envolvidas nos assentamentos desaparecem do processo e da reportagem, contrariamente ao que é fixado e evidenciado, ou seja, o propósito do governo em intensificar os projetos de expansão agrícola. Esse caminho seguido no texto banaliza tanto as mudanças ocorridas no espaço quanto as relações sociais dos assentados, pois o pensamento que objetivava a expansão agrícola é o que está mais aparente no discurso da época.

Os deslocados, anteriormente, eram em muitos casos, arrendatários ou posseiros no Sul. Com a ameaça da alagação do espaço onde viviam, viram-se levados a se deslocarem para o meio urbano ou participar dos projetos de assentamentos desenvolvidos na Amazônia acreana, o que, a princípio, representava uma solução, sendo que não havia forma de garantir a permanência nas terras devido à alagação. Embora haja a decisão de mudar por situações exteriores às suas decisões individuais, a aceitação do distanciamento não se deu de forma simples ou singular, algo evidente nas narrativas orais que seguem.

A família de Dona Olívia veio para o Acre após a intervenção de uma colonizadora no Oeste do Paraná encarregada pelo deslocamento dos colonos atingidos pela barragem. Hoje, com 56 anos, aparenta ser uma mulher com traços de sofrimento marcados no rosto. Ao chegarmos a sua casa, na cidade de Sena Madureira, esta apresentava uma feição muito comum às pessoas do Paraná, o seu tom de voz e seu jeito de falar, ainda resgatavam os traços do lugar de onde veio. Ela estava feliz pela visita e naquele momento queria saber sobre a importância de sua história, isso por achar que suas experiências eram tão individuais que não ecoavam dentro de um contexto maior. Sentada em uma cadeira, na cozinha de sua casa, um lenço vermelho desbotado amarrado na cabeça, usava uma saia sem estampa, com um tímido godê e na altura da canela, como também uma blusa solta e desbotada pela ação do tempo, assim Dona Olívia começou sua narrativa traçando todos os detalhes que a memória lhe possibilitou. 
Relatou que ela e seu marido moravam com os filhos no Paraná, próximos a Foz do Iguaçu, local que ela denomina como "área da Itaipu" onde sofreria a alagação pela represa. Arrendavam terras para trabalhar e sobreviver economicamente, entretanto o que conseguiam era insuficiente para tratar dos filhos, então trabalhavam por dia em outras propriedades. A família não possuía a terra o que ocasionava a migração onde houvesse trabalho no campo e segundo ela, a vida sempre foi um ir e vir em busca de trabalho. Chegar ao Acre foi além de uma escolha, também uma saída para a situação social na qual viviam. A promessa de ganhar uma propriedade fez com que essa família se deslocasse, ela só possuía a força de trabalho e apropriar-se da terra, ser o dono, significava ascensão social, como também plantar e colher sem ter de vender a força de trabalho para o patrão. Era o processo de emancipação econômica da família através das promessas dos dirigentes de Itaipu.

Eles conversaram com as pessoas toda, aí eles disseram: "o único jeito que nóis tem que levá voceis é pro Acre" nóis falemo assim: pra onde levá nóis tem que ir, porque, com criança pequena, né? Sem sabe pra onde tem que ir". Só que pra Araputi num tinha mais vaga...Nóis quiria ir pra lá , mas não tinha mais vaga.O jeito que tem é...ou então ir aqui pro Acre, ou Bahia ou pro Paraguai. Nóis preferiu aqui no Acre. Aî viemo, marcô o dia, aí nóis viemo. Viemo em três ônibus, em quatorze família. E três caminhão com um pouco de mudança, né, cada família...Três ônibus com 14 família e 3 caminhão. Só que nóis viemo tudo de graça. Só que nóis também não tinha dinheiro, porque nóis plantemo só um pedacinho de milho que foi o Lindào e meu minino mais velho que fez, enquanto nóis trabalhava por dia. E o home, ficô de pagá nóis no fim do ano e ele não pagô porque ele logrô o patrão dele. Porque ele era arrendatário do patrão e nóis era dele, né? Aí ele ficou devendo pro patrão e veio embora pra Rondônia, né? E nóis ficamo na mão, aí só vendimo aquele pedacinho, aquele pouquinho de milho, e, ainda o fazendeiro veio e ainda pegô a metade. Mais a roça nós num tinha pegado do fazendeiro, mas do empreiteiro dele, né? Aí ele foi, vendeu o milho pra nós e ainda tirô a renda dele. Aí fiquemo lá, comendo, bebendo,sem trabalhá e sem arrumá serviço. $\mathrm{O}$ vizinho andô um meis e num achô serviço. Aí eles mando nóis pra cá. Aí viemo com 3 ônibus, remédio, comida, leite pras criança, tudo. E os 3 caminhão vinha pra trás, só com um pouquinho, o resto larguemo lá na casa, mandaram fogo (FERREIRA, 2012). 
Dona Olívia, cuja família passou pela experiência do deslocamento, iniciou sua narrativa tentando colocar uma ordem cronológica nos "acontecimentos" de sua trajetória, entretanto, na proporção em que, no momento da entrevista, todos de sua família estavam presentes, passaram a produzir lembranças e representações das experiências vivenciadas. Nesse significativo processo, muitas vezes, um lembrava algo que o outro esquecia, num verdadeiro "atropelamento" de vozes.

Nas lembranças da família de Seu Toninho e Dona Olívia percebemos o que eles experimentaram quando foram deslocados. Cada pessoa da família expressava sua maneira de sentir e ver o ocorrido, entretanto, o sofrimento durante a viagem e a fixação no novo território se deu de forma coletiva. $\mathrm{Na}$ época em que desocuparam as terras no Sul por causa do Lago de Itaipu o mais importante no rumo político do governo estava em enviar as pessoas sem posse de terras para a região amazônica, o que resolveria parte do problema da alagação e ainda contribuiria para o projeto dissimulado de reforma agrária da ditadura militar. Dois processos aconteceram de forma simultânea, um era resolver o problema de uma parte da população brasileira que era "sem terra", arrendatária e que necessitava sobreviver através do trabalho no campo, como é o caso da família de Dona Olívia; o segundo era um objetivo do governo militar em assentar trabalhadores rurais na Amazônia caracterizando a reserva de trabalho e expansão agrícola, ações ressaltadas de forma velada nos discursos expansionistas.

Os projetos de assentamento na Amazônia já estavam sendo discutidos pelos tecnocratas. A década de 1980 já apresentava a ideia amadurecida pelo governo da época, como podemos apreender a partir da interpretação que os redatores de Gažeta do Acre faziam sobre a "migração" para a região.

Mesmo com investimentos nos planos de colonização, o território, até na década de 1960, dependia exclusivamente do extrativismo vegetal, ainda à margem do processo de desenvolvimento do país, isolado das demais regiões e desarticulado do restante do sistema nacional. Quando essa iniciativa foi tomada pelo governo, Rondônia foi beneficiado com uma infra-estrutura básica de transportes, tornando acessíveis aos grandes centros os recursos naturais existentes no território. A partir daí, rápidas transformações se verificaram: 
A abertura da BR-364 permitiu grande migração proveniente do Centro-Sul incentivada pela existência de terras da União e sua distribuição pelo INCRA aos colonos dispostos a adquirilas e fixar-se na região (GAZETA DO ACRE, 29/01/1981).

A ideia de "progresso", na opinião do redator da matéria, nos leva a perceber uma clara recusa em reconhecer a importância das práticas culturais presentes no interior da floresta, em especial, o extrativismo que é tratado como "à margem do processo de desenvolvimento do país". Daí por diante, somos remetidos às cristalizadas noções de "isolamento geográfico" e da necessidade de exploração dos chamados "recursos naturais" da região.

Matérias como esta representam a visão singular sobre as questões migratórias para a Amazônia, ressalta o desenvolvimento sem observar as formas como os deslocados se relacionariam com a terra, pois traziam consigo outras formas de produção e outra relação com a floresta. Para esses trabalhadores rurais recém-chegados, derrubar as matas era o primeiro passo para iniciar a produção, era um ato despreocupado e natural como há muito havia sido feito em outras regiões do país. Esse trabalhador rural, de certa forma, representa a vontade de desbravar, isso pela tradição migratória que o povo do Sul carrega em suas experiências históricas. Derrubar a mata fazia parte do trabalho árduo, limpar o espaço para o plantio já era uma estratégia conhecida pelos sulistas, nesse aspecto, eles não se sentiam jogados a própria sorte. Tinham como referência experiências anteriores de ocupação na região de onde vieram. Mesmo depois de três décadas permanece o sentimento de querer plantar e colher, fazer roçado, expandir a propriedade, isso é visto na fala de outro migrante morador no Ramal 16 e conhecido como Cebolinha: "Agora tá difícil é o negócio de agora pra frente que a gente num pode mais fazê roça, nada mais, que os cara num deixa mais roçá, né?”.

Florindo Reis, entrevistado em Sena Madureira, discorre sobre o deslocamento de sua família para o norte e marca em sua fala tanto a falta de terra no sul, como a abundância de terras no Acre onde não havia limites para o desmatamento.

Num tinha terra, não. Se prantava um amendoim, era dividido. 
Se tinha de a meia, era de a meia, se fosse setenta por cento [pausa] Era desse jeito. Mas nóis num tinha terra lá, não. Porque a terra era muito caro naquela época. Era muito caro. Nóis era sem terra, era tudo assim, se nóis fazia um plantio de mio, um plantio de arroz, que o arroz lá só dava se fosse no banhadão, na terra mais baixa, se fosse no alto num dava de jeito nenhum. Aí era tudo 30\%, né? Num é que nem aqui, né? A gente comprô uma terra, pegô uma terrona. Aquele nosso ali que nóis pegô 43 alqueire, 43 alqueire de terra e disse: "isso aqui é dóceis". Aí fomo tratá o tanto que qué. Aí a gente podia derrubá o tanto que queria, naquele tempo podia derrubá o tanto que quisesse. Se quisesse derrubá tudinho de uma veiz, podia derrubá. Agora num pode mais. Num pode mais (REIS, 2012).

A narrativa oral de Florindo aparenta demonstrar o sentimento de rejeição ao Sul quando comenta a situação de arrendatário à qual a família estava submetida. A preferência de Florindo pela nova realidade demonstra, de maneira implícita, os conflitos e angústias atribuídos à realidade deixada representando a exploração do trabalhador rural. Os trinta anos passados e que separou os dois lugares não foi suficiente para aniquilar algumas angústias experimentadas no Sul como a falta de terra para plantar. Ainda é preservado na fala de Florindo o sentimento ao vender o trabalho por ser arrendatário e deixar setenta por cento do trabalho com o patrão, o que justifica um dos motivos que os impulsionaram para o deslocamento.

A fala de Florindo também marca a possibilidade de ver o que representava derrubar árvores para plantar produtos da agricultura, sendo que a relação do sulista com a floresta difere da relação do acreano, pois cada um teve uma vivência e consequentemente as práticas de sobrevivência distinguemse. O trabalhador do Sul tinha marcado em suas experiências o desmatamento e o tratamento necessário da terra para começar a produzir, como é verificado na fala de Florindo: "Aí fomo tratá o tanto que qué", a abundância de terra representa a prosperidade encontrada no novo espaço.

A maneira de ocupação, exploração e organização do espaço trazida pelo trabalhador rural do Sul, distancia-se da forma adotada pelo trabalhador rural acreano. No Acre o extrativismo foi a prática usada por aqueles 
que estavam no interior da floresta, já o sulista chegou com novas práticas de ocupação que se baseavam na agricultura, necessitando de produzir e de escoar a produção, nesse sentido há uma recorrente insatisfação quanto aos ramais que usavam para se locomoverem e transportarem seus produtos.

Para pensar os deslocados sulistas recém-chegados ao Acre e suas práticas e resistências é necessário resgatar, através da historiografia, os motivos que os impulsionaram para uma mudança de território. Com isso caímos em datas, causas e consequências da construção da Usina Hidrelétrica Itaipu Binacional, que representou a forte tendência desenvolvimentista do governo militar e que, de certa forma, também foi motivo de "desocupação de 1.350 quilômetros quadrados" (GERMANI, 2003, p.184) de terras produtivas entre o Estado do Paraná e o Paraguai.

O pensamento que embasava as ações da ditadura militar não previa as mudanças que seriam impostas às pessoas que necessitariam de deslocamento. As experiências e práticas sociais construídas pelas famílias ao longo do tempo na região oeste do Paraná nada significavam para aqueles que almejavam a construção da usina. Itaipu representava a ideia do novo, a ideia da "modernidade".

Nesse caso, o capital fica concentrado no domínio de poucos, o que muda o panorama do campo, portanto, "fazendas se transformam em 'fábricas agrícolas' e os camponeses que não abandonam o campo se transformam em proletários campesinos" (BERMAN, 1989, p.90). Os sulistas deslocados dessa narrativa passaram por essa experiência ressaltada por Berman, fato que os levaram a procurar uma saída dentro do contexto capitalista de modernidade.

Sendo Itaipu uma representação do projeto de modernidade idealizado pelo governo militar, procuramos dialogar com o processo histórico de sua construção, que teve início muito antes da década de 1970. O seu primeiro suspiro, sua primeira célula de vida estava no Governo de Juscelino Kubitschek com a ideia de "progresso e desenvolvimento" para o país. Assim, segundo Germani (2003), surgiu discussões sobre o aproveitamento do potencial hidrelétrico do rio Paraná e os primeiros estudos geográficos na região, sempre 
lembrando que os debates não aconteciam com a participação dos trabalhadores rurais que seriam futuramente atingidos, nem se pensava nas dificuldades que seriam encontradas, menos ainda nos problemas que o lago poderia causar às pessoas que ocupavam as terras e que delas viviam.

Mas o modelo de desenvolvimento não poderia parar e dando prosseguimento ao projeto do Governo JK, havia a necessidade de estabelecer acordos com os países vizinhos: Argentina e Paraguai. Isso se dava por conta do conflito histórico na região da Bacia do Prata, pois esta foi palco de diversas tensões na história. Desde a colonização, já havia o interesse de Portugal e Espanha pela região devido a sua localização.

Para tratar com um olhar econômico, recorremos a Gallo (2005) que traça as questões surgidas diante das relações internacionais ocorridas entre o Brasil e os países vizinhos. Assim, vimos que havia a importância econômica da Bacia do Prata, por participar de uma grande parte do PIB (Produto Interno Bruto) dos cinco países e qualquer alteração na navegação dos rios que formam a bacia poderia também afetar economicamente os envolvidos.

Visitamos as questões econômicas e políticas que se relacionavam com os países da Bacia do Prata. Além do potencial de navegação e econômico, a bacia também apresentava o hidrelétrico, que é de "60 a 70 kw e seus principais rios e afluentes proporcionam 15 mil quilômetros de vias navegáveis constituindo a única saída natural para o mar para a Bolívia e o Paraguai, pelo Oceano Atlântico" (GALLO, 2005, p.64). A Argentina dependia das águas do rio Paraná no plano hidro energético e no desenvolvimento industrial. Já o Paraguai estava mais bem situado, o que lhe proporcionou um poder maior de negociação, ele dividia fronteiras tanto com a Argentina, quanto com o Brasil através das águas do rio Paraná. Sua localização geográfica possibilitava fazer acordos com ambos os países.

A partir das questões econômicas, devido à localização geográfica dos países platinos, surgiam também os primeiros conflitos gerados pela vontade de cada país em fazer o aproveitamento do potencial hidrelétrico e, simultaneamente, a exploração do econômico. A escolha do local para a constru- 
ção da barragem colocava em risco o projeto Corpus ${ }^{3}$, que seria localizado a 250 quilômetros abaixo de Itaipu. Com o represamento do Rio Paraná, a navegabilidade no trecho argentino seria comprometida, além de impossibilitar o projeto Corpus (JORNAL DA REPÚBLICA, 10/10/1979).

Diante do cenário de conflitos, o maior obstáculo foi promovido pela Argentina, pois as concepções desenvolvimentistas e geopolíticas dos militares do Brasil e da Argentina viam a importância da geração de energia para a industrialização dos dois países que estavam interessados no desenvolvimento nacional e na "modernização". Era necessário pensar na ampliação da capacidade energética do país para abrir o mercado da industrialização e sustentar o modelo econômico desenvolvimentista, a construção de Itaipu afetaria a exploração energética dos rios. Foi a partir dos confrontos entre os dois países que as chancelarias conseguiram chegar ao acordo que estabelecia o represamento de Corpus a 105 metros do nível do mar, o que não afetaria ou "afogaria" Itaipu e em contrapartida também faria alteração no seu projeto inicial para que a Argentina desse prosseguimento ao projeto Corpus (O ESTADO DE SÃO PAULO, 21/08/1979).

Com os acordos consagrados podia-se colocar em prática o projeto hidroenergético de 1961, esboçado pelo Engenheiro militar Pedro Henrique Rupp, ainda no governo do Presidente Janio Quadros. Tal projeto previa uma usina antes da fronteira com o Paraguai, e no Governo de João Goulart (1961-1964) o Ministério das Minas e Energia incumbiu outro engenheiro, Otávio Marcondez Ferraz, que já havia dirigido a construção da Usina Paulo Afonso, de aprofundar os estudos feitos no Governo anterior por Rupp. Com isso foi retomada a ideia anterior de construir uma usina, exclusivamente, brasileira. Tal fato nada agradou ao governo e ao povo paraguaio, gerando manifestações nas ruas de Assunção, "protestos contra o governo brasileiro e seu desejo expansionista” (MAZZAROLO, 2003, p. 21) e ainda impossibilitava desenvolver o projeto Corpus.

O potencial energético do Rio Paraná representava para

3 Trata-se de um projeto de construção, discutido em 1978, de uma usina hidrelétrica entre Argentina e Paraguai que exploraria a capacidade energética do Rio Paraná. 
o Brasil e a Argentina acesso ao "desenvolvimento" e a "aceleração" econômica, mas não eram previstos os problemas sociais e os conflitos com os desapropriados e atingidos por barragens. O Brasil argumentava que seu desejo era de soberania e, no anseio de realizar o sonho de "desenvolvimento", encontrou outro obstáculo: o Paraguai. O governo brasileiro não respeitava o acordo feito em 1872, assinado e denominado como Tratado de Limites, "que definiu como pertencente aos dois países, em condomínio, o trecho do rio Paraná que banha ambos" (MAZAROLLO, 2003, p. 21). Essa faixa de terra em conflito era mais conhecida como "faixinha" (GERMANI, 2003) e, em 1965, foi ocupada pelo Brasil, causando protestos no país vizinho:

O General Golberi Couto e Silva, chefe do Serviço Nacional de Informação do Brasil, que se encontra desde anteontem em Assunção, é enviado pessoal do presidente Humberto Castelo Branco, para considerar o problema suscitado por motivos de ocupação dos Saltos de Guaira por tropas do Brasil, o que está provocando uma crescente onda de protestos no Paraguai (ÚLTIMA HORA, 28/11/1965).

As relações entre o Brasil e o Paraguai ficaram melindradas gerando uma crise entre ambos, estabelecida através de protestos vindos dos universitários e jovens militantes do Partido Colorado que invadiram e depredaram a sede da Missão Cultural e Comercial do Brasil em Assunção, que, após atear fogo e queimarem algumas bandeiras brasileiras "saíram em passeata pelas ruas evocando a Guerra da Tríplice Aliança e acusando o Brasil de 'sanguinário, aproveitador dos fracos"” (MAZAROLLO, 2003, p.23).

O Governo Paraguaio via as notas que o Brasil publicava sobre o conflito e não aceitava o posicionamento de domínio do território pelos militares que estavam na zona conflituosa, como também a sociedade paraguaia cobrava um posicionamento do então Presidente Alfredo Stroessner. Os jornais paraguaios criticavam a atitude do Brasil e, naquela época, manifestavam o desejo de retirada da Embaixada do Brasil, como também da Missão Militar Brasileira.

Em 16 de fevereiro de 1966, o jornal "Última Hora", transcreveu a matéria do diário paraguaio La Libertad. É importante nesse mo- 
mento observar na nota do jornal as implicações do momento no qual foi escrita. O Brasil vivia a ditadura militar, o jornal necessitava da voz do outro para mostrar a indignação do governo paraguaio.

Exército Brasileiro que com brutal arrogância assentou seus quartéis em território paraguaio, tantas vezes santificado pelo sangue nacional é a evidência de que tudo contorna um plano geralmente manejado pelo Itamarati para despojar o Paraguai dos seus legítimos direitos na zona dos Saltos, exigimos que pelo menos, nossa justa indignação tenha outras manifestações mais adequadas que a emissão de notas que permanecem nos arquivos brasileiros, em que os dirigentes do Itamarati os lancem com desprezo (ÚLTIMA HORA, 16/2/1966).

O Paraguai via como imprudente e provocadora a permanência do Brasil na área de litígio com isso a situação se agravava, significativamente. O desejo brasileiro de explorar o potencial energético do Rio Paraná seria ameaçado e mais ainda, fazê-lo sozinho já era uma dificuldade estabelecida. Mesmo assim, o governo da ditadura brasileira, insistia em usar argumentos que "desfiguravam a realidade". Os editores do "Última Hora" teciam suas leituras e representações sobre o conflito, pontuando que, durante alguns meses de desentendimento entre os dois países, o Brasil apresentaria uma nota pública, a partir da qual procurava esclarecer seu posicionamento à ocupação repentina do território em condomínio.

O conflito pela "Faixinha" ganhou tamanha repercussão que o Departamento de Estado norte-americano fez uma intervenção, propondo um encontro entre os chanceleres do Brasil e do Paraguai em prol de um acordo apaziguador. Tal "encontro" ocorreu em 22 de junho de 1966, dando origem a um documento denominado "Ata do Iguaçu", que instituiu uma Comissão Mista de Limites e Caracterização da Fronteira Brasil-Paraguai, incumbida de levantar as possibilidades de exploração energética do Salto de Sete Quedas até a foz do Rio Iguaçu. Após os acordos estabelecidos e selados, o momento era propício para iniciar o grande projeto de construção da usina.

Inquietos e atentos aos conflitos, acordos e protocolos na fronteira sul do país, os trabalhadores rurais da região acompanhavam seus 
desdobramentos. Das encenações e "rugidos" das casernas do Brasil e do Paraguai, uma série de impactos se abateria sobre os homens e mulheres daquela área de fronteira, deslocando-os para outras localidades, como pontuou Dona Elza, mulher de 65 anos, trabalhadora rural, natural do estado do Espírito Santo, que morou na faixa de litígio, próxima aos Saltos de Guairá e depois no Paraguai.

Ah sim, eu conheci muito lá! As pessoa que moravam na faixinha, né? Lá dava o nome faixinha que era na beira do rio Paraná. Então, tinha muita gente do meu esposo que morava lá. Tinha tio, primo, tinha muita gente. Muita gente mesmo, lá! Eu tava contando pros minino [aponta para os filhos e netos]. Aí quando foi nesse tempo, a Itaipu indenizou eles. Só que aqui eu num conheço ninguém deles aqui. Eu conheço em Rolim de Moura, em Rolim de Moura tem bastante deles ainda. Tem parente dele ainda que mora ali, que foi desapropriado. Foi assim: O governo pagô. O governo indenizô e eles sairo. Uns foram pro Maranhão, compraro terra no Maranhão, outros comprồ no Mato Grosso, outros comprô na Rondônia. Mas foi muita gente que saiu. Eu morava na faixa do rio, o nome era faixinha. Eu morei lá também. Só que depois eu saí de lá, eu vim pro Rio Bonito, que é Paraná, me lembro que lá também é Paraná, depois que eu fui mais pra frente, depois que eu voltei pro Paraguai (DIAS, 2012).

Dona Elza desnuda a forma como as pessoas eram tratadas, em um momento no qual o aspecto financeiro gerado pelas indenizações era a única preocupação dos dirigentes de Itaipu. O governo pagava e as pessoas saiam, mesmo que a contra gosto. O trabalhador rural deixava sua casa, suas plantas, sua história e era deslocado, separado de suas raízes e de seu passado que ficaria submerso, embora vivo nas lembranças. A resistência desse trabalhador não estaria no campo argumentativo, no campo das palavras, mas na sua resistência interior de deixar de pertencer ao seu lugar de origem, que não mais existiria após o alagamento.

A desocupação era uma obrigação, uma ordem em nome do "desenvolvimento" do país. A mobilidade dessas pessoas, especificamente, apresenta-se diferente das correntes migratórias dos sulistas gaúchos nos estados do Mato Grosso e Rondônia, a partir da década de 1970. No modelo econômico 
de expansão das fronteiras agrícolas, o produtor rural deslocado se encaixava perfeitamente nos objetivos da ideia de reforma agrária do governo militar, portanto, além de ser resolvido o problema da expropriação de terras devido ao alagamento de Itaipu, eles também serviriam para ocupar os espaços geográficos que, no discurso do governo, eram espaços vazios.

As famílias atingidas pela barragem de Itaipu caracterizavam-se como "pessoas simples" (GERMANI, 2003), sem muita escolarização e, outrora, vindos dos estados de Santa Catarina e Rio Grande do Sul, descendentes de alemães e italianos em busca de um espaço para plantar e colher. Participaram da história da colonização da região Oeste do Paraná, fizeram benfeitorias nas terras e cotidianamente trocavam experiências com os demais. A realidade desses trabalhadores baseava-se na harmonia entre os vizinhos e as trocas de favores e cooperação que se transformavam em experiências e vivências coletivas.

A ideia de inundação de grandes espaços não era concebida pelos agricultores, o imaginário deles impossibilitava ver cidades, vilas e muitas fazendas submersas pelo reservatório da usina. A representação de espaço para eles era materializada apenas através de uma distância segura das águas do Rio Paraná para não sofrerem enchentes. Eles possuíam uma linha imaginária entre a água que subia em épocas de chuvas e a propriedade, sendo uma enorme dificuldade entender que seriam tomados pelas águas do lago.

Além disso, essas pessoas não compreendiam o processo que estavam vivenciando, não sabiam como exigir seus direitos à terra e negociar com os dirigentes de Itaipu, não refletiam sobre as consequências que sofreriam com a desapropriação e deslocamento. Mas havia ainda outro grupo que não era formado nem por proprietários, nem por posseiros, mas por arrendatários, como é o caso de algumas famílias que foram deslocadas para a Amazônia e que colaboraram para esta pesquisa contando suas histórias e experiências vividas durante e após a alagação. Essas famílias sem posse de terra fazem parte do grupo de deslocados que foram enviados para a Amazônia acreana em busca de oportunidade. No imaginário formulado a partir das experiências anteriores que possuíam no Sul, ganhar terra para trabalhar acompanhava os anseios antigos ligados às condições que vivenciavam enquanto famílias de sem terra. Chegando 
aos assentamentos, as dificuldades foram aparecendo com a falta de ramais e condições de trabalho. Nos relatos, mencionaram a falta de estradas nos PADs, onde foram assentados pelo INCRA, o que dificultava o escoamento da produção. Esse trabalhador rural vinha de outra realidade, de outra região e esbarrou nas dificuldades do clima, especialmente, os períodos de chuvas, que, além de ser diferente daquilo que conheciam, dificultava a retirada do que produziam.

Cebolinha, filho de uma família que chegou em 1982, foi entrevistado no município de Sena Madureira e chegamos até ele por indicação de um funcionário do INCRA que não autorizou a gravação de entrevista. O funcionário do INCRA de Sena Madureira, mostrou um documento antigo que estava guardado desde a época do assentamento no PAD Boa Esperança. Dentre as famílias que vieram, estava o nome do pai de Cebolinha que mora, no momento, em Acrelândia, mas Cebolinha é proprietário de uma colônia no Ramal 16, ${ }^{4}$ ele desloca-se até a cidade para vender o queijo que produz. Coincidentemente, em um dos dias dedicados às entrevistas em sena Madureira, foi possível encontrá-lo.

Ao procurá-lo, a primeira referência era a casa de amigos, mas ele não estava lá. Deram-nos como indicação a casa do sogro, local onde, provavelmente, ele passaria. Não foi muito difícil identificar a pessoa procurada. Ele estava sentado na varanda de uma casa de madeira, em cuja frente havia uma rua com uma pavimentação típica da região. Nada delimitava a casa do espaço da rua onde trafegavam pedestres e carros. Ao longe, as características físicas coincidiam com as mencionadas pelo funcionário do INCRA. Seu cabelo é liso, espetado e loiro, os olhos claros, azuis e o nariz afinado. A pele judiada, queimada e manchada pela ação do tempo e do sol, insinuando marcas de experiência de vida na colônia.

Ele se mostrou propenso para participar da pesquisa, mas sentia-se constrangido, sempre olhava para um lugar inexistente, como alguém que busca em algum ponto as lembranças adormecidas no universo da memória. Pouco falou do passado. Ressaltou que veio muito cedo para o Acre, afirmava não se lembrar de detalhes da viagem, pois era criança na época.

${ }^{4}$ Ramal 16 é o nome de uma estrada que dá acesso às colônias que fazem parte do PAD Boa Esperança no município de Sena Madureira, Acre. 
Afirmou que seu pai não era proprietário das terras no Paraná, fato que possibilitou delimitar o grupo de deslocados. Assim percebemos na quinta entrevista que as famílias com as quais mantínhamos contatos não eram os donos da terra onde viviam no Paraná. A família de Cebolinha deslocou-se para a Amazônia em busca de prosperidade através da posse de terra. Buscávamos detalhes da viagem, queríamos "resgatar" os "fatos acontecidos": as indenizações de Itaipu, as negociações e as práticas que os envolviam no espaço onde viviam. O entrevistado não revelou com detalhes as experiências vividas, falou muito mais da sua vida no tempo presente. Para ele, sua realidade presente se sobrepõe às lembranças, contou pouco da infância no Acre e pouco da viagem e praticamente nada do que viveu em sua terra natal, apesar de situar geograficamente a região onde nasceu e onde viveu até os oito anos.

É perceptível o sentimento de ruptura com o espaço, a separação umbilical e a situação de obrigação em vir. A família de Cebolinha seguiu o rumo que os dirigentes de Itaipu indicaram, não houve uma vontade espontânea, uma decisão voluntária para mudar. Portanto, por motivos e circunstâncias, muitas famílias como a de Cebolinha deixaram seus espaços com significados construídos e foram arrancados, deslocados, trazendo apenas na memória a lembrança de experiências vividas no Paraná.

Veio não, veio não! Só veio eu mais minha ...[não concluiu a palavra que possibilita ser família] O pessoal de lá, os outro ficaro tudo lá, as parentada nossa ficaro tudo lá, só viemo nóis por causa da coisa da Itaipu. Foi feita a, o negócio da barrage, né? Aí nois saimo de lá tarde, como, não sei como faço dizê, fumo indenizado, né? Eles fizero uma comunicação pras parte, né? Saimo de lá pra cá por causa disso, num tinha onde [pausa novamente] Aí foi onde eles dero um rumo pra nóis vim foi pra cá. Porque se nóis quisesse vim pro Acre, porque tinha terra, tinha terra, né? (TELLÓ, 2012).

É possível verificar nessa fala, como também nas outras entrevistas, um aspecto relevante que descortina características semelhantes entre as famílias assentadas no Acre: não eram proprietários de terras paranaenses. Com a alagação das áreas onde viviam, foram obrigados a reconstruir um novo 
caminho, motivo que impulsionou o deslocamento para uma região que não conheciam e não imaginavam com clareza as diferenças que encontrariam em diversos aspectos.

Nas narrativas orais são ressaltadas as dificuldades tanto das estradas entre sul e norte, como também aquelas entre a colônia e a cidade. O programa de expansão agrícola para a região amazônica estimulava o assentamento das famílias nos PADs, mas nem todas as estradas de acesso estavam abertas, o que, segundo os relatos prejudicava o escoamento de produção e o trânsito que as famílias necessitavam entre o campo e a cidade. Na fala de Cebolinha fica marcada a falta de estradas o que representa o desconforto que sentiam.

Aqui naquela época era muito ruim, né? Agora, miorô mais, mais né? Num tinha asfalto, num tinha nada, agora tá cada veis mais milhor. Vige naquela época era muito ruim, vige, nóis pra vim na cidade aqui era uma luta, né? Agora tá miorando mais, né? Cada veis mais...Em vista do que era, né? Aquela veis, pra Manoel Urbano mesmo num tinha asfalto, num tinha pra Rio Branco, e, agora tem, tem tudo (TELLÓ, 2012).

Ao refletir sobre as condições estruturais dos assentamentos descritas nas narrativas, encontramos a recorrente referência feita aos ramais, que simbolizam as maiores dificuldades enfrentadas logo na chegada. Tanto na entrevista feita com Cebolinha, como em outras, o tempo de inverno amazônico e as condições dos ramais foram os maiores desafios no novo espaço. Entretanto, essas pessoas tiveram de encontrar caminhos para o enfrentamento e adaptação à nova situação apresentada. Cebolinha, em outra situação da entrevista destaca que "só difícil é só o ramal, só o Ramal 16, ir lá que é difícil , né? As veis a lama dá no meio da perna , lá no inverno, mais a gente, gente vai e vence, é só no inverno mesmo aí melhora de novo, é assim". Após trinta anos morando no mesmo assentamento, as dificuldades de locomoção tornaram-se rotineiras durante o tempo chuvoso, hoje Cebolinha sabe que com o verão o "ir" e "vir" deixa de ser um obstáculo.

Refletindo sobre o "fazer-se sujeito do jeito do lugar chegado”, Jones Dari Goettert observou que a produção de representações sobre os espaços se dá pelas experiências que acontecem nas relações sociais, sendo que "a representação sobre os lugares do passado e do presente se dá, em especial, sobre 
a vida neles transcorrida" (GOET'TERT, 2008, p.169). Essa percepção nos levou a ter outro olhar para as narrativas/relatos de espaço que mencionam a questão da falta de ramais e outras vias de acesso e escoamento de produtos.

$\mathrm{Na}$ fala de Cebolinha é possível verificar vários significados que manifestam os sentimentos e as dificuldades vividas não só por ele, mas também por outras famílias de deslocados. Embora haja sinais de cansaço e fastio de anos enfrentando o mesmo problema, apresenta também uma força além do que o corpo possibilita, uma batalha que tem como objetivo garantir não apenas uma colônia para trabalhar, mas também de sentir o seu pertencimento ao lugar. Uma luta cotidiana que aproxima, fixa e enraíza esse trabalhador rural ao espaço, que o faz se identificar através de suas vivências e labutas.

Quando nas entrevistas a situação precária dos ramais e estradas torna-se recorrente, há sempre uma comparação entre presente e passado como na fala "Agora tá miorando mais, né? Cada veis mais". Esse aspecto representa a aceitação das melhorias das estradas se contrapondo ao sentimento de desaprovação pelas condições piores quando chegaram aos ramais. Todo esse resgate torna-se possível porque a memória possibilita, e, ao mesmo tempo as lembranças vão tomando significados a partir do que há no presente para ser observado. Cada fala, que menciona as melhorias dos ramais, representa também que aquele deslocado que chegou em 1982 sente-se parte do espaço onde está hoje, ele faz e fez parte do processo de pertencimento, sente-se como testemunha de um passado e isso o faz sentir-se da terra.

De certa forma lembrar produz outro significado pela ação que o tempo presente desempenha. As experiências do vivido conferem outro significado à memória, transformam-na e, ao mesmo tempo, dão o tom de alívio por terem superado as dificuldades que o deslocamento proporcionou. Ao ouvir as falas dos entrevistados e seus enfrentamentos para adaptação ao novo contexto sócio-histórico e geográfico que passaram a vivenciar, foi possível perceber que há em suas histórias a experiência do "fazer-se", no sentido thompsoniano, após o rompimento físico e emocional com o lugar de origem.

Cada experiência narrada tem seu significado singular. 
Embora as pessoas tenham participado de experiências muito parecidas, ou que tenham vindo por situações e razões semelhantes, as narrativas se diferem. As experiências vividas depois de chegaram à Amazônia acreana, ao mesmo tempo em que se aproximam, também se distanciam em alguns aspectos, pois cada deslocado assimilou para si os processos mais significativos e, no momento da narração, são esses processos que vem à tona em suas narrativas.

Dona Elza, matriarca da família, deixou claro em seus traços e dizeres, a força que teve de ter para superar as questões adversas que o momento exigia. Seu marido era doente, ela precisava tomar decisões para garantir o sustento da família. Para Dona Elza a situação dos ramais durante o inverno dificultava sua locomoção quando um filho adoecia ou quando tinha de buscar remédios para o marido, mas em suas lembranças a maior dificuldade foi a doença do marido aliada à situação dos ramais.

O mais difícil aqui que eu encontrei, primeiro foi a doença do meu esposo, depois os ramal pra andá. Num tinha asfalto. Eu, muitas vez eu vinha de lá de pé, lá da colonha até aqui. Era vinte quilômetros, vinte quilômetros, lá da colonha até a $\mathrm{BR}$, agora é 3 , é $23 \mathrm{~km}$. Eu vinha buscá as coisa dele doente, né? Ele doente. Teve uma veis que eu vim cum ele, ela era cumprida, mas era magrinha. Ela num era gorda assim, agora que ela casô, arrumô um casamento ficô assim. Mas quando era pequena, ela adoeceu com uma febre e eu com medo de malária, né? Porque pra lá dava muita malaria e eu cum medo. Aí vinhemo, vinhemo e chegô na estrada arrumava um carro, daí um pouquinho atolava. Deixava aquele carro, aí pegava essa minina botava em cima do carro, descia essa menina do carro, Eu tirava essa menina e punhava no chão, e assim foi. Cheguei aqui. Cheguei aqui e fumo na SUCAM. A SUCAM ainda era lá em cima e agora nem sei onde que é a SUCAM. Aí levei ela lá, aí fez a lâmina e num deu malária. Aí levei no hospital, consultaro, passaro um remédio, ela deu uma melhorada. Aí falei "vamo embora Vera". E o pai dela doente lá. Minina, aí foi difícil mesmo!! Peguemo uma carona cum caminhão, aí cheguemo no caminho cabô a gasolina, ali na fazenda Brasil. Foram atrás de uma gasolina por lá, a gente andô mais um pedacinho. Aí andando a pé e essa menina com uma canseira, cansada, eu fazia que num tava vendo que ela tava ruim, pra vê se ela andava. Andei um pedaço bom assim, ela vinha atrás 
de mim. Aí o outro cara que vinha com nóis disse - Dona sua menina tá passando mal! - Aí eu falei que não é porque ela tá cansada. Peguei água no meio da estrada assim naquela vala, eu pensei será que faz mal dá essa água pra ela? Água bem clarinha, mas uma fundura assim, ó! Poção onde os carro passava, aí lavei o copo que ia levando, eu tinha emprestado pra eles botá gasolina no carro. Aí eu peguei lavei aquele copo bem lavadinho e banei aquela água, tirei a água e dei pra ela bebê. Ela bebeu e nóis fomo, quando nóis fomo e chegô no ramal, aí é mais difícil! Duente, subi aquela ladeira num era fácil! Mas aí foi, eu pensava assim sozinha: eu vô andá na frente que ela vendo eu andá ela anima e anda, né? Aí eu andava, se caí eu volto e pego. Carrego até eu guentá, né? Aí fomo, quando nois chego lá essa bichinha amanheceu no outro dia com os pé dessa grossura de andá, doente e andá! (DIAS, 2012).

A distância entre a colônia e a cidade é intensificada por Dona Elza, ela faz uma caracterização colocando em evidência o percurso de vários quilômetros andados, que se multiplicavam durante o tempo de inverno amazônico, o que representa a dificuldade pela qual passava. A doença do marido e a suspeita de malária da filha fundem-se com os obstáculos que significavam as estradas sem estrutura. Elencando os níveis de dificuldades, ela categoriza o que vinha primeiro, ou seja, o ramal sem condições de tráfego, que não se sobrepunha diante da possibilidade de perda do marido ou da filha. Em sua reflexão, tais obstáculos fundiam-se.

Ouvindo Dona Elza narrar sua experiência, contando todos os detalhes, enumerando as dificuldades e as possibilidades de enfrentamento da situação, fica perceptível que a realidade necessitava de táticas para ultrapassar as dificuldades, diante das adversidades ela conseguia superar os obstáculos que na narrativa parecem intransponíveis. A localização da colônia de Dona Elza a empurrava em dificuldades de locomoção durante o período de chuva, mesmo assim, essa senhora que hoje fica na cidade no período de inverno amazônico, fala da colônia com saudosismo "Aí então, né? A gente vai ficando velho, né? Aí num tem mais jeito, tem que ficá aqui só com a saudade!", isso demonstra o sentimento de pertencimento que ela tem com a colônia, a vida no meio rural faz falta para o seu cotidiano, a situação do ramal não rompe os laços que ela tem 
com o apego à colônia. Um novo deslocamento se instala na vida de Dona Elza.

Sempre procurando formas e alternativas para sair das situações adversas e manter o sustento e união da família, essa trabalhadora conseguiu um fomento para a construção da casa na colônia, entretanto, o recurso veio muito depois, após dois anos, quando ela já havia improvisado a construção de uma casa de madeira. Ela não usou o dinheiro para reformar ou construir uma nova casa, porém foi buscar uma de suas filhas que havia ficado no Estado de Rondônia e que estava há dois anos sem dar notícias.

Aí vim pra cá, aí quando passo, daí dois ano, nóis tava nessa casinha, aí saiu o dinheiro da casa. Eu pensei: Ah! Eu já fiz essa casinha, tá bom demais! Ai falei Adilson, nisso a mãe do Adriano escreveu uma carta pra mim, fazia dois ano que eu num sabia noticia dela. Ela escreveu uma carta. Aí eu falei: olha eu vô pegá esse dinheiro, sabe o que eu vou fazê, eu vou procurá a Zinha. Se eu achá bem, se eu num acha eu volto. Aî falei com esse filho meu que mora lá. Ele falou: mãe é bom pra senhora ir mesmo, o bom é que a senhora passeia, a senhora distrai um pouco, outro a senhora vê ela (DIAS 2012).

O procedimento de Dona Elza configurou-se em forma de enfrentamento da situação precária, era necessário criar alternativas que garantissem a união da família. Com essa opção, Dona Elza mostrou-se definida e decidida, tomando a iniciativa de usar um recurso do governo para resolver seus problemas familiares. Em uma visão simplista é possível contestá-la pela decisão, entretanto, há uma coerência na atitude devido à situação que se apresentava no momento. Para essa senhora, cuidar da família transcendia as leis impostas pelos créditos ofertados através de incentivos da política agrícola.

Outra situação relatada por Dona Elza menciona um financiamento que ela conseguiu para plantar pupunha, em suas palavras foi possível ver a determinação que a movia, pois a terra representava a prosperidade, quando a vizinha a indagou dizendo "Dona Elza, a senhora tem coragem de pegar um financiamento de 12 mil reais?”, a resposta foi clara e demonstrou o quanto ela acreditava no seu trabalho afirmando "eu tenho, porque eu tenho a terra, eles tão me dando, e, com fé em Deus eu vô pagá!" 
Segundo os relatos de Dona Elza quando o dinheiro chegou, ela resolveu comprar bezerros e vacas, o que possibilitou o pagamento da dívida, entretanto, o recurso era destinado ao plantio de pupunha. Ela conta que em uma reunião com outros produtores, era a única que estava conseguindo pagar as dívidas apesar de não seguir exatamente as regras estabelecidas pelo sistema de financiamento. Depois, por uma política do governo, conseguiu pagar menos da metade do que devia. Hoje ela possui pouco gado, todos estão pagos e ela se sente tranquila, tem a colônia e uma casa na cidade de Sena Madureira.

O significado da colônia para Dona Elza é de prosperidade, embora ela seja aposentada. Ainda mantém a terra que seu filho cuida, mas seu desejo é de ficar permanentemente por lá, entretanto, com a idade avançada, a viuvez e as dificuldades de locomoção, é mais coerente ficar no meio urbano durante o inverno amazônico.

Até hoje quando eu vou pra lá parece que ele tem que chegá! [refere-se ao marido] Toda tarde parece que ele vem! Foi duro! Aqui num foi tanto, a casinha num foi tanto que eu dormia sozinha! Mas lá, até hoje é difícil. Mas num vim pra cá por causa disso aí. Eu num vim pra cá por causa que ele morreu não, eu vim pra cá por causa da estrada. Igual eu tava contando pra voceis. Mas parece assim, quando vai dando uma tarde lá, parece que ele vinha do roçado, né? E aí tô aí! Quando eles fala pra mim casá, eu tenho vontade de dá uma peia ne quem falá! (DIAS, 2012).

Dona Elza também vê os ramais encontrados nos assentamentos logo que chegou como um dos obstáculos que ela teve de transpor, e, hoje se sente empurrada para o meio urbano, pois não possui a mesma disposição física para se locomover durante o inverno. Surge uma relação plural de Dona Elza que permanece como deslocada, entre o meio rural e urbano, ela continuamente se depara com o sentimento de pertencimento e não pertencimento.

No caso de Dona Olívia, outra deslocada que também se mostra como alicerce da família, as experiências com a colônia são apresentadas de forma diferente. A família se dedicou à agricultura, não fez financiamento para comprar gado, ela diz: "Meu marido nunca fez financiamento, ele tinha mui- 
to medo de não conseguir pagá." A família tentou por quase trinta anos viver do plantio, mas as dificuldades de locomoção por causa do ramal, a exaustão causada pelo cansaço físico acumulado durante todos esses anos, os levaram a decidir pela venda da terra para vizinhos fazendeiros.

Hoje Dona Olívia e seu Toninho moram na cidade de Sena Madureira, vivendo em uma casa simples, mas não pagam aluguel. Os dois são aposentados, o que garante uma vida regrada, mas certa. Uma das filhas e seus dois netos moram na mesma casa, além do filho caçula do casal. Dona Olívia consegue circular na política de assistência social do governo, com o "benefício" de uma "Bolsa Família". "Benefício" esse que também está conseguindo que a filha. A família considera que morar na cidade só trouxe prosperidade, pois a vida na colônia era muito difícil. A locomoção nos ramais, em tempo de chuva, era um obstáculo que o avançar da idade e a perda de força física tornavam difíceis de superar.

O deslocamento para a cidade das duas entrevistadas se deu por fatores semelhantes, representa a busca pelo melhor espaço para viver na velhice, entretanto, o significado que a colônia possui para cada uma se dá de forma diferente. Dona Elza mostra amor pelo meio rural e sente saudades, mas pela idade e solidão da viuvez acha mais sensato seguir os conselhos dos filhos e morar no meio urbano. Dona Olívia não sente vontade de voltar para a colônia, segundo ela na cidade as coisas são mais fáceis e confortáveis, ressalta nessa decisão de viver no meio urbano, a questão de não ter mais idade para enfrentar a lama nos ramais. Nesse caso cada experiência mostra-se singular e o desfecho no tempo presente liga-se a tais vivências que cada uma das entrevistadas passou.

As pressões econômicas definiram o "ir" e "vir" das famílias atingidas pela alagação, direcionaram o caminho a seguir, e, continuaram definindo também no novo espaço que encontraram. As decisões tomadas para praticar o espaço que encontraram são vistas a partir da narrativa oral, e com as análises há além de um olhar que apenas registra, pois o diálogo com relatos orais ajuda a tecer uma rede de significações que pode transcender o econômico e agrupar questões subjetivas As histórias de vida possibilitam enxergar as relações individuais e coletivas no sentido assumir uma posição política e encerrar no 
texto ora apresentado as várias representações daquilo que os diferentes sujeitos dessas histórias fazem diante do vivido.

Encerramos com Guimarães Rosa (2006) para quem “de cada vivimento que eu real tive, de alegria forte ou pesar, cada vez daquela hoje vejo que eu era diferente pessoa". As pessoas que passaram pela experiência do deslocamento para a Amazônia acreana além de terem muito para contar envolvendo alegrias, tristezas, desafios e lutas, passaram também por transformações. As experiências às quais foram submetidas às levaram a uma visão de passado com outros significados, o que é possível ser visto quando nos debruçamos sobre suas formas de interpretar e significar suas trajetórias a partir de narrativas orais no tempo presente.

\section{From aCREAN AMAZON: NARRATIVES OF THE DISPLACED WORKERS FROM ITAIPU - READINGS FROM THE "PRESENT TIME"}

ABSTRACT: This article is about the journey of men and women displaced into Acrean Amazon after the land expropriation occurred in the municipalities around Lake Itaipu, at the end of the 1970s. The context is that of the construction of the Itaipu Hydroelectric Dam, which lead to the inundation and confiscation of rural properties and the deportation of the residents. This work proposes an approach centred on the perception of cultural practices and displacements as rooted in time and space through oral narratives. In addition to direct testimonies, this work used as evidence newspapers from the time, which often idealised the construction of the dam and attempted to "record" the conflicts with the people who were expropriated, alongside with the official propaganda on the "state-directed colonisation" of the Amazon region.

KEYWORDS: Itaipu. Acrean Amazon. Oral Narratives. Modernisation. Rural Workers.

\section{Referências}

ARENDT, H. A condição humana. Tradução: Roberto Raposo.Rio de Janeiro: Forense Universitária, 2010.

BENJAMIN, W. Magia e técnica, arte e política: ensaios sobre literatura história da cultura. Tradução: Sérgio Paulo Rouanet, São Paulo: Brasiliense, 1994. 
CERTEAU, M. A invenção do cotidiano: Artes de fazer. Tradução: Ephraim Ferreira Alves, Petrópolis, RJ: Vozes, 2012.

COSTA, C. A conquista do deserto ocidental: subsídios para a história do território do Acre. Ministério da Cultura / Fundação Cultural do Estado do Acre, Rio Branco, 1998.

DIAS, E. F. Entrevista realizada em 15/02/2012

FERREIRA, Olívia dos Reis. Entrevista realizada em 16/02/2012.

GERMANI, G. I. Expropriados, terra e água: o conflito de Itaipu. Salvador: EDUFBA: ULBRA, 2003.

GOETTERT, J. D. O espaço e o vento: olhares da migração gaúcha para o Mato Grosso de quem partiu e de quem ficou. Dourados, MS: Editora da UFGD, 2008.

MAZZAROLO, J. A taipa da injustiça: esbanjamento econômico, drama social e holocausto ecológico em Itaipu. São Paulo: Loyola, 2003.

REIS, F. Entrevista realizada em 15/02/2012.

ROSA, G. Grande sertão: veredas. Rio de Janeiro: Nova Fronteira, 2006.

SAID, E. Fora do lugar: memórias. Tradução: José Geraldo Couto, São Paulo Companhia das Letras, 2004.

SAID, E. Reflexões sobre o exílio e outros ensaios.Tradução: Pedro Maia Soares, São Paulo: Companhia das Letras, 2003.

SARLO, B. O tempo passado: cultura da memória e guinada subjetiva. São Paulo: Companhia das Letras, 2007.

SARLO, B. Paisagens Imaginárias. Tradução: Rubia Prates Goldoni e Sérgio Molina. São Paulo: Editora da Universidade de São Paulo, 2005.

TELLÓ, C. A. Entrevista realizada em 16/02/2012

THOMPSON, P. A voz do passado: história oral. 2. Ed. São Paulo: Paz e Terra, 1998.

Data de recebimento: $11 / 08 / 2014$

Data de aceite: 25/09/2014 